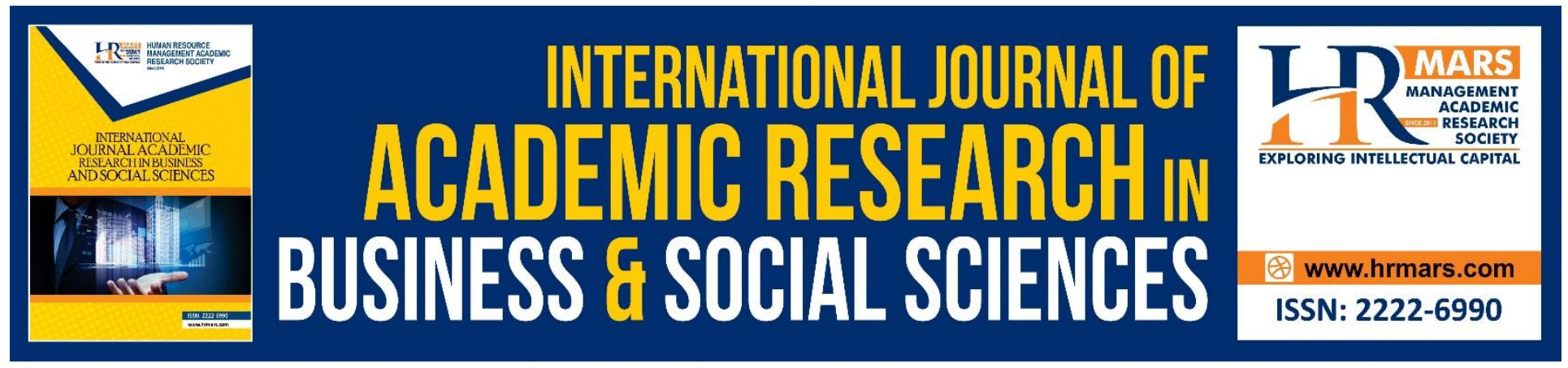

\title{
Project Planning and Development of The Health Educational Module (Hem) on Childhood Obesity Management (Com) For Primary School Children In Malaysia: Conceptual Framework
}

Norimah Said, Norazmir Md Nor, Nurul Fadly Habidin, SitiSabariah Buhari, Siti Khuzaimah A Sharoni

To Link this Article: http://dx.doi.org/10.6007/IJARBSS/v9-i2/5658

DOI: $\quad 10.6007 /$ IJARBSS/v9-i2/5658

Received: 09 Feb 2019, Revised: 26 Feb 2019, Accepted: 12 March 2019

Published Online: 18 March 2019

In-Text Citation: (Said, Nor, Habidin, Buhari, \& Sharoni, 2019)

To Cite this Article: Said, N., Nor, N. M., Habidin, N. F., Buhari, S., \& Sharoni, S. K. A. (2019). Project Planning and Development of The Health Educational Module (Hem) on Childhood Obesity Management (Com) For Primary School Children In Malaysia: Conceptual Framework. International Journal of Academic Research in Business and Social Sciences, 9(2), $1193-1209$.

Copyright: (C) 2019 The Author(s)

Published by Human Resource Management Academic Research Society (www.hrmars.com)

This article is published under the Creative Commons Attribution (CC BY 4.0) license. Anyone may reproduce, distribute, translate and create derivative works of this article (for both commercial and non-commercial purposes), subject to full attribution to the original publication and authors. The full terms of this license may be seen

at: http://creativecommons.org/licences/by/4.0/legalcode

Vol. 9, No. 2, 2019, Pg. $1193-1209$

http://hrmars.com/index.php/pages/detail/IJARBSS

JOURNAL HOMEPAGE

Full Terms \& Conditions of access and use can be found at http://hrmars.com/index.php/pages/detail/publication-ethics 


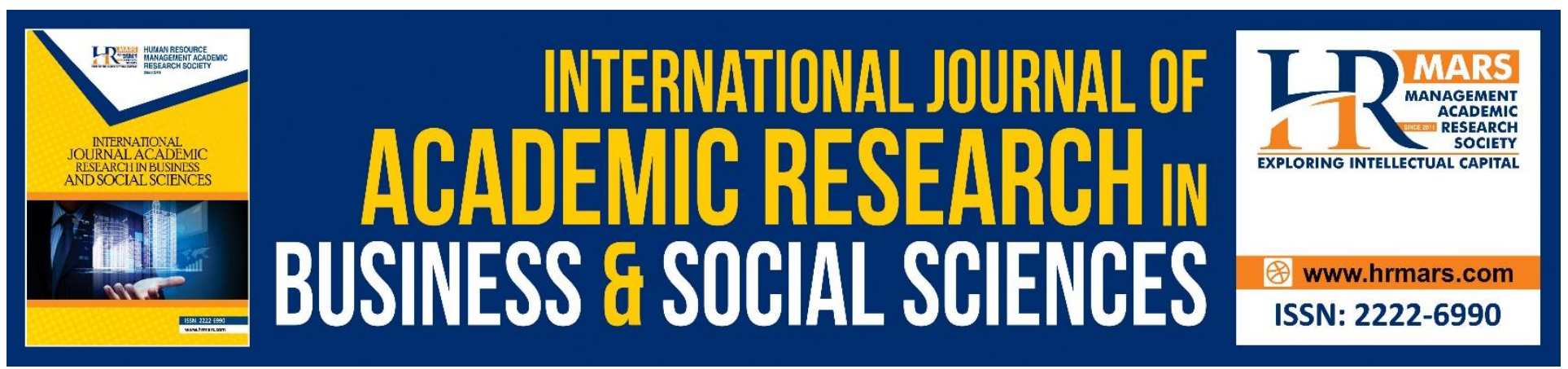

\title{
Project Planning and Development of The Health Educational Module (Hem) on Childhood Obesity Management (Com) For Primary School Children In Malaysia: Conceptual Framework
}

\author{
Norimah Said ${ }^{1}$, Norazmir Md Nor², Nurul Fadly Habidin², \\ SitiSabariah Buhari², Siti Khuzaimah A Sharoni ${ }^{1}$ \\ ${ }^{1}$ Centre for Nursing Studies, Faculty Health Sciences, Universiti Teknologi Mara (UiTM) \\ ${ }^{2}$ Centre of Dietetic and Nutrition, Faculty Sains Kesihatan, Universiti Teknologi MARA \\ UiTM Puncak Alam Campus, 42300 Puncak Alam, Selangor \\ ${ }^{3}$ Faculty of Management and Economic, Universiti Pendidikan Sultan Idris \\ MALAYSIA
}

\section{Abstract}

This article discusses the concept for the development of the Health Educational Module (HEM) on Childhood Obesity Management (COM) for primary school children aged 7 to 12 years old concerning the prevalence of overweight and obese children below 18 years old in Malaysia that continues to increase. The methodology consists of an experimental design with pre and post-test questionnaires followed by Fuzzy Delphi Method for primary school children and parents. Therefore, the development of this module hopes to be able to prevent obesity among children. The purpose for the development of HEM is to enhance knowledge, practice behaviour, attitude and self-efficacy among primary school children aged 7 to 12 years old. The CHANGE design will be applied for this module that contains the health education on nutrition, activities and guide exercises for the overweight and obese school children. Development of HEM is based on the Generalized Model for Program Planning (GMPP). The primary outcome of HEM will be evaluated through the knowledge, practice and attitude on nutrition and physical activity, level of physical activity, sedentary lifestyle and Body Mass Index (BMI) of the overweight and obese school children. The findings from the development of HEM will provide new findings on the future health education and promotion in primary schools in Malaysia to facilitate the effective management of childhood obesity towards prevention of obesity.

Keywords: Development, Obesity, School Children, Module, Fuzzy Delphi 
INTERNATIONAL JOURNAL OF ACADEMIC RESEARCH IN BUSINESS AND SOCIAL SCIENCES

Vol. 9, No. 2, Feb, 2019, E-ISSN: 222 2-6990 @ 2019 HRMARS

\section{Introduction}

Overweight and obesity are defined as an abnormal or excessive fat accumulation that may impair health (WHO, 2012). The definition of obesity is not limited to fats content and how fats are stored in the body; instead, obesity can be defined as the distribution of body fat. Indeed, excess abdominal fat is a significant risk factor for disease as excess body fat (WHO, 2014). Overweight and obesity are major risk factors that may lead to some chronic diseases including type 11 diabetes, cardiovascular diseases, sleep apnoea, and orthopaedic problems (Berry, Savoye, Melkus, \& Grey, 2007; Kitzinger \& Karle, 2013). Obesity can affect primary school children psychosocially especially concerning their image. They commonly have lower self-esteem compared to other children.

Childhood growth and development is dependent on the nutrition status and they need optimal nutrition to maintain their health and constant growth - this supports the importance of the nutrition program that was implemented in Malaysian schools since the 1970s. An example of the activities that have been implemented are School Feeding Programme (Rancangan Makanan Tambahan (RMT) in the year 1979 by Ministry of the Education Malaysia and the School Milk Programme (Program Susu 1 Malaysia) in the year 1983 (Kementerian Pendidikan Malaysia, 2015). Besides that, the Malaysian Ministry of Education and Ministry of Health have collaborated through the implementation of the School Canteen Management Guideline where healthy catering training is conducted for the school canteen. Therefore, the Guidelines on the Prohibition of foods outside the school perimeter (Ministy of Health Malaysia, 2012) was implemented as the prevention programme supports the importance of nutrition for the school children. Also, the Students Health Record (Rekod Kesihatan Murid, (RKM) and the SEGAK (Ujian Standard Kecergasan Fizikal Kebangsaan) program was implemented to monitor the nutritional status and level of fitness among school children (Krishnaswami, 2017). Based on these previous initiative strategies plans, the Malaysian Government has shown an emphasis on the preventative programme and monitoring of health status of the school children.

\section{Background of Project Primary Prevention program in Malaysia}

The awareness and prevention measures are required for the prevention of obesity. The school children should be given health education instruction as guidance for them to avert potential health problems. Also, the primary prevention is key to preventing obesity from rising further. It can be defined as the preventive measure that forestalls the onset of illness or injury before the disease process begins (McKenzie et al., 2008). It focuses on health education, health promotion, and disease prevention programs. This means that the target of the program is more towards modifying the risk factor as well as inherited, environmental and behavioural influences including sedentary lifestyle and poor dietary habits which the individual can change or control (Cottrell, Girvan \& Mc Kenzie, 2009). The past decade has seen the rapid development of health education and health promotion in many aspects including the combination of planned learning experiences using evidence-based practices, political, environment, organizations that support by the theories, and actions that are able to enhance knowledge, attitude, and practices that are needed by individuals, groups and communities to adopt and maintain healthy behavior (Foundations of Community and Public Health, 2018). 
Meanwhile, the Malaysian Ministry of Health has prioritised primary prevention to prevent the increasing number of diseases. The problem of obesity needs to be addressed through primary prevention. An example of primary prevention that was implemented in schools is "Rancangan Kesihatan Sekolah" since 1989 (Surat Pekeliling Ikhtisas, 1998). This guideline shows the important role of the school. According to the American School Health Association (ASHA,2007), school health education involves all the strategies, activities, and services offered by, in, or in association with schools that are designed to promote student's physical, emotional, and social development. The school health programme should be coordinated and integrated with various aspects including food services, nursing services, school counselling and psychology, health instruction, physical education, administration, school environment, community involvement, and faculty or staff wellness (Centre for Disease Control and Prevention, (CDC,2018). This means that the school health program has the potential to affect significant changes in school eating habits for the school children in a positive way to reduce the prevalence of obesity.

Several activities were implemented at the school level such as nutrition and physical education programmes. Nutrition education is also known as food education and provides information about nutrition and combines with the physical activity. Besides that, nutrition education among school children is essential for improving their knowledge on healthy eating and how to choose healthy foods following the Malaysian choice of food (Schey, Luther, \& Rose, 2016). A part of it would improve the knowledge, attitude, and practices toward caring for health and receiving an inadequate nutrition intake. This is supported by a previous study which found that the development of a nutrition education program is able to promote healthy dietary habits especially for students and families (Vio, Fretes, Montenegro, González, \& Salinas, 2015).

\section{Factor Contributing to Obesity Among School Children.}

An interactional cause of obesity could be due to environmental factors, genetic predisposition, and human behavior. Being overweight or obesity among children is generally caused by a lack of physical activity and unhealthy eating habits, besides the genetic and social factors such as socioeconomic status, race, ethnicity, media and marketing, and the physical environment that also influence energy consumption and expenditure (Koyuncuoğlu Güngör, 2014).

However, the lack of knowledge related to nutrition has also been identified as a contributing factor to obesity among school children. It has been well documented from a previous study that knowledge is necessary to make the right nutritional decisions to improve health, performance and growth (Doughlas, 1984; Shifflett, 2002). Knowledge of food and nutrition is deemed essential in promoting healthy eating habits that subsequently reduce the prevalence of obesity (Triches \& Giugliani, 2005). Lack of knowledge among school children is more on choosing a healthy diet such as the importance of consuming fruit and vegetables and avoiding sweet beverages that contribute to the increasing prevalence of obesity among school children. This is because school children are likely to eat fast food, causing a deficiency in consumption of fruits and vegetable (Dewantari \& Widiani, 2011). This supports that the value of nutritional knowledge is a target for health education and is a crucial part of promoting healthy eating (Wardle \& Parmenter, 2000).

Meanwhile, data from the Malaysia School-Based Nutrition Survey (MSBNS) in 2012 suggests that school children are supposed to consume at least three servings of vegetables and two servings of fruits. However, $93.7 \%$ of children consumed less than the basic guideline for vegetables and 
INTERNATIONAL JOURNAL OF ACADEMIC RESEARCH IN BUSINESS AND SOCIAL SCIENCES

Vol. 9, No. 2, Feb, 2019, E-ISSN: 222 2-6990 @ 2019 HRMARS

51.7\% consumed less than two servings of fruits (Institute for Public Health (IPH), 2013). The consumption of fruits and vegetables has many benefits for school children. It provides a source for dietary fibre, vitamins, and minerals that act as an anti-inflammatory agent and fibre intake is helpful in reducing the number of cases related to cardiovascular disease and obesity (Slavin \& Lloyd, 2012). However, many of the school children are eating unhealthy food and practice unbalanced eating habits such as the consumption of sweets and carbonated drinks as well as not consuming enough water, fruits, vegetables, and skipping their breakfast (Ahmad \& Rahman, 2014).

Besides that, most of the school children aged 6 to 17 years old informed that they skipped breakfast more than three times a week as reported by My Breakfast Study of School Children in 2013 (Nutrition Society of Malaysia, 2015). Furthermore, high nutrition knowledge is more common among girls and those from urban areas (Naeeni et al. 2014). Therefore, there is a need to address healthy eating practices as early as possible.

Furthermore, one of the predicted factors of obesity is a sedentary lifestyle and a lack of practicing healthy behaviour such as a healthy lifestyle. It is also related to poor attitude towards healthy eating. Poor diet and a lack of exercise and physical activity are the two leading causes of an increased prevalence of childhood obesity (CDC, 2018). Most children are likely to be watching television, playing video games or using a computer rather than taking part in outdoor activities such as jogging where $43 \%$ of children watch television more than two hours per day (Akhtar-Danesh et al., 2011; $\mathrm{He}$, 2007). These situations may increase the prevalence of childhood obesity. This is related to poor attitude towards a healthy lifestyle and healthy eating. In developing a positive attitude towards healthy eating, there is a need to incorporate good dietary practices from early childhood until adulthood (Kigaru et al., 2015). Although, a lack of self-efficacy among primary school children and empowerment to make the right decision on the chosen healthy food, healthy eating, and healthy lifestyle contribute to the prevalence of obesity. Hence, self-efficacy is developed through learning by examining past performance, observing others, verbal persuasion, and physiological cues (Pekmezi, Jennings, \& Marcus, 2009).

Another social issue that needs to be address at the individual level in preventing obesity is the parental role. Positive parental modelling of physical activity and nutrition are crucial to teaching value to the children. Savage, Fisher, and Birch (2007) claimed that parenting techniques at home could have a powerful influence on the development of children's food preferences, intake patterns, diet quality, growth, and weight status. Nonetheless, parental control and pressure to eat may also influence dietary intake and disrupt children's short-term behavioural control of food intake (Savage et al., 2007). Thus, controlling the children's food intake is better than being restrictive to encourage the development of culturally appropriate eating patterns and behaviours in children. Meanwhile, a mother is the closest person to any child and is also the first person who will introduce healthy behaviours in shaping their children's lifestyle. So, a mother plays a vital role in fighting childhood obesity. However, to reduce childhood obesity effectively, the mother needs to be motivated and to understand healthy eating patterns and exercise that helps her child lead a healthy life (AkhtarDanesh et al., 2011; He, 2007). 


\section{Prevalence Obesity}

The prevalence of obesity among children were identified from developed countries and are on the rise in developing countries (Tung, Shamarina \& Mohd Nasir, 2011). In the United States of America (USA), the prevalence of obesity among 2 to 19 -year-old children remains at $17 \%$ (Nutrition Examination Survey (NHANES, 2012). However, the prevalence of obesity in the USA has decreased to $14.94 \%$ from $15.21 \%$, and extreme obesity is at $2.07 \%$ (CDC US, 2012 ).

Furthermore, the European Union shows the prevalence of overweight and obese school children at $35 \%$. This means that there were 1.3 million children per year are overweight and obese in the year 2010 (Jackson-Leach \& Lobstein, 2006). In other countries such as the United Kingdom, Spain, Italy, and Southern Europe, the obesity prevalence was at around 19\% to 35\% in the year 2011(Serene, Shamarina, \& Mohd, 2011). In Australia, it was found that being overweight is more prevalent among girls (22.1\%) as compared to boys (20.7\%) (Schultz, 2012).

As a conclusion, the rate of overweight and obesity has increased over the years in developed countries where the increasing trend is $83 \%$ out of 1.5 million of the world children population (Cameron \& Norgan, 2006).

Not only that, childhood is obesity in developing countries also increasing (Tung, Shamarina \& Mohd Nasir, 2011). Thailand, for example, is one of the countries where the prevalence of childhood obesity was $13.7 \%$ for obese and $5.3 \%$ for overweight and more prevalent among boys with $18.9 \%$ as compared to girls with $10.8 \%$ (Sengmeuang, Kukongviriyapan, Pasurivong, Jones, \& Khrisanapant, 2010).

According to the Report National Morbidity Health Survey (National Health and Morbidity Survey 2015 (NHMS, 2015), Malaysia is a developing country with the National prevalence of obesity among children (BMI for age) was $11.9 \%$. NHMIS reported that Perak had the highest prevalence of obesity at $14.1 \%$. The state with the lowest rate of obesity in Malaysia were Sabah \& WP Labuan at only $8 \%$. This report also stated that the prevalence of obesity was slightly higher in urban areas at $12.1 \%$ as compared to rural at $11.2 \%$ and was more significant among boys with $13.6 \%$ as compared to girls with $10.0 \%$. The data showed that children $10-14$ years old had $14.4 \%$ rate of obesity.

In Selangor, a previous study reported the prevalence of childhood overweight and obesity at $16.3 \%$ and $6.3 \%$, respectively (Zaini et al., 2005). Kuala Selangor was reported to have a prevalence of $14.6 \%$ for overweight and 7.2\% for obese in the year 2006 (Sumarni Mohd et al., 2006). In the Federal Territory of Kuala Lumpur, the prevalence of overweight and obesity was reported to be at 13.7\% (Muhammad et al., 2008). However, a report by HMIS (2015) stated that Selangor was at number 4 for the prevalence of obesity after Perak, Sarawak, and Penang. That being said, Selangor still has $13.3 \%$ prevalence of obesity in the population of school children of 199,501.

Childhood obesity has been an emerging health problem in developing countries, especially in urban and suburban areas. Action is required for preventive measure for the emerging obesity problem. In the Malaysian context, preventive measures take the form of a change in lifestyle, eating habits, and food intake.

In conclusion, future research on the development of the health education module on nutrition education, physical activity, and obesity prevention will result in the improvement of knowledge, practice behaviour, attitude, and self-efficacy for primary school children and prove to be beneficial if the design module prevention for obesity facilitates methods such as monitoring and evaluation. 
Furthermore, another suggestion includes training programs on the promotion of nutritional behaviours as well as informing families, especially women, about healthy foods, methods of cooking healthy and diverse foods that are adaptable to the tastes of all family members, and appropriate lifestyle including regular exercise, reducing duration television viewing, reducing the consumption of fatty and fast foods, and increasing the consumption of fruits and vegetables to control weight and prevent all types of obesity (Khodaveisi, Omidi, Farokhi, \& Soltanian, 2017).

Most of the intervention or prevention programmes focuses on an urban area as compared to suburban or rural area. The effects of the prevention or intervention program in Malaysia are still questionable because of the lack of continuous implementation during the entire school year for the prevention or intervention of obesity and ability to keep school children engaged and motivated after joining the programme. An example of the new intervention programme has been piloted in Negeri Sembilan is H.E.B.A.T by Universiti Kebangsaan Malaysia in 2016 which is a control trial intervention to combat childhood obesity. However, the programme needs support from government and private sectors as well as policy-makers in formulating childhood obesity intervention (Sabariah, Ruzita \& Poh, 2017). Although for continuous support, the prevention or intervention programme needs aid from the stakeholders, and parents to ensure the programme is effective in combating obesity (Mohd Shah, Norimah, Appukutty, Thirukanesh, Bong \& Ismail, 2017). Besides that, the Malaysian Ministry of Health and Malaysian Ministry of Education need to see that identifying and evaluating obesity among children in Malaysian schools as an important avenue to ensure that all children are physically and mentally active (Sabramani et al., 2015). Coaching the identified obese school children in reducing their fat or effective health education regarding weight management among the children, teachers, and parents can also be carried out.

\section{Generalized Model for Program Planning (GMPP)}

Development of this educational module is based on the Generalized Model for Program Planning(GMPP) (Mc Kenzie et al., 2009). This model provides guidelines for pre-planning and developing an educational program with a variety of approaches and allows the module planner to answer key questions and will help to understand school children and engage the priority of that group (audience) (Foundations of Community and Public Health, 2018 ; Mc Kenzie et al,2017).

The understanding and engagement in this process means discovering as much as possible information related to the priority of group and environment it exists in (Foundations of Community and Public Health, 2018). This model provides five tasks as Figure 1:
a. Assessing the needs of the priority population
b. Developing an appropriate goal and objective
c. Creating an intervention that considers the peculiarities of the setting
d. Implementing the intervention
e. Evaluating the results.

This model suggests the health education that will be developed, and planning must be careful and systematic. Furthermore, the developer of the program or module must have skills, and a health educator must understand their work and use planning models to make sure the program or module is successful (Cottrell, Girvan \& Mc Kenzie, 2009). 


\section{Project Description}

The purpose of this project is to develop and evaluate the HEM on Childhood Obesity Management (COM) for the Primary School in Malaysia.

At the same time, this project is interested in answering several research questions and hypothesis on whether the development of this module will make a significant difference on the knowledge, practice behavior, attitude, self-efficacy and body mass index (BMI) before and after the implementation of the educational module. This project provided an important opportunity to advance the understanding of the adoption framework that was developed by Centers for Disease Control and Prevention (1999) which included six steps (1) engage stakeholder, school and school children, (2) describe the module, (3) evaluation design, (4) gather credible data, (5) justify conclusion, and (6) ensure the use and share lesson learned as illustrated in Figure 2. Thus, to ensure the module complies to these six steps, it should be evaluated by an internal evaluator who was involved in the implementation module and an external evaluator who will evaluate this program from the outside that we can call the observer.

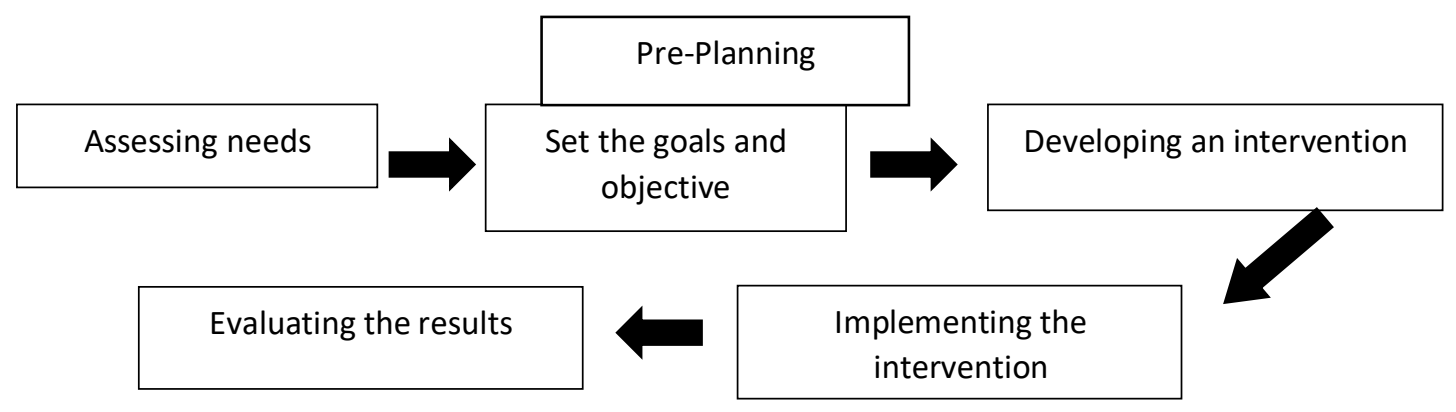

Figure 1: Generalized model for program planning ( GMPP)

Source: adopted from Mc Kenzie, J.F., B. L, Neiger, and R. Thackeray. Planning Implementing, and Evaluating Health Promotion Programs: 5/e. (2009)

This project will be deployed in three phases as referred to Figure 3:

a. Phase one: Needs assessment

Needs assessment among primary school children to identify their need for health education related to the prevention of obesity. This assessment will be conducted on the questionnaire, document, systematic review, and literature review. This educational module will be developed from the analysis of the need's assessment and comments from experts. The comprehensive educational module will be developed based on several topics related to nutrition, physical activity, and obesity prevention. The design of the module will be determined based on the Centres for Disease Control and Prevention (2015), Malaysian Dietary Guideline (MDG) for Children and Adolescent 2015, National Institute for Health and Care Excellence (2014), My Health (2008), and World Health Organization (2000).

a. Phase two: Set the objective and develop the HEM

In relation to the literature review done, the design of the educational module will employ the "C.H.A.N.G. E" design where the $\mathrm{C}$ refers to Choose, $\mathrm{H}$ refers to healthy, $\mathrm{A}$ refers to activity, $\mathrm{N}$ refers 
to nutrition, G refers to guide, and E refers to exercise. In other words, C.H.A.N.G.E means "Choose Healthy Activity, Nutrition, and Guide Exercise" The educational module will provide the intervention with various instructional design regarding health education to primary school children related to nutrition, physical activity, and prevention of obesity to enhance their knowledge, attitude, practice behaviour, and self-efficacy. The parent will also receive information related to nutrition, physical activity, and the prevention of obesity as well as how they can play the role at home to enhance the information to their children. The first design and module that has been completed will be evaluated by the experts to ensure the HEM is valid and reliable. After that, the module will be modified again before the implementation. After the modification, the HEM will be tested or piloted to verify the module.

b. Phase three: Implementation and evaluation of HEM.

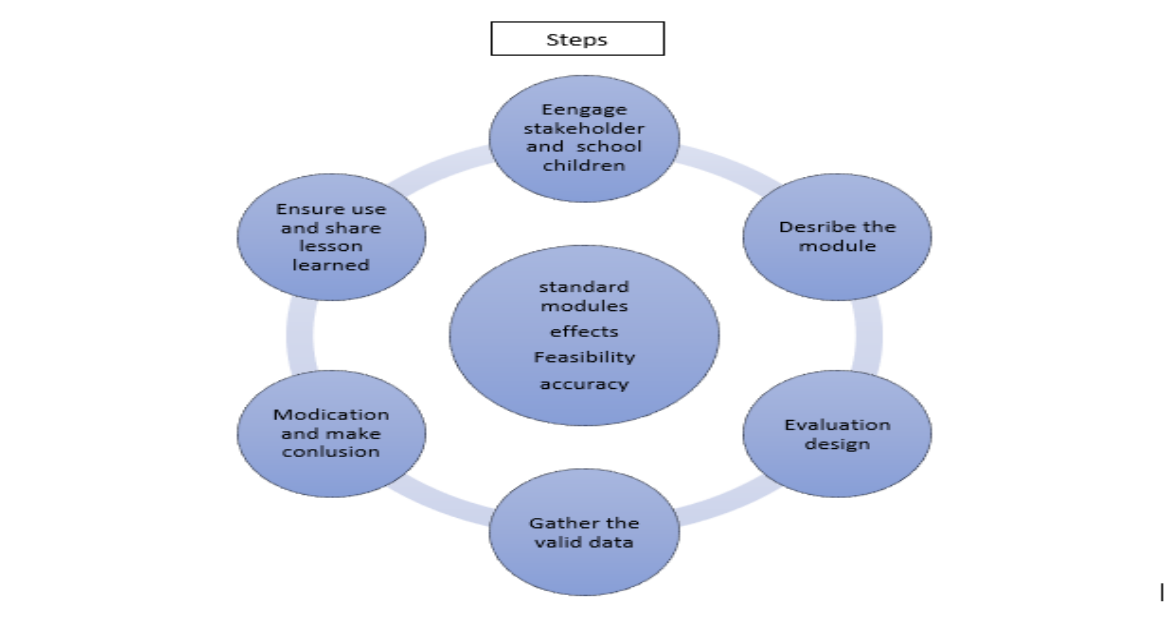

Sources: adoption from: Centres for Disease Control and Prevention (1999). "Framework for Program Evaluation in Public Health. "Morbidity and Mortality Weekly Report, 48 (RR-11), 1-4O

Figure 2:

\section{Framework for HEM evaluation}

This project will employ an experimental design with two groups: the intervention and control groups. A school that has been categorised as an intervention will receive the HEM to evaluate the effect of the module, both pre and post. Meanwhile, a school in the control group will receive the traditional routine for health education by using a pamphlet, along with evaluation on both pre and post.

\section{STUDY PROTOCOL}

HEM Module Intervention Protocol as shown at the Figure 3.

The researcher will obtain the written permission from the Malaysian Ministry of Education, followed by Jabatan Pendidikan Negeri and the school that has been chosen with random sampling. Schools that have given their permission will be classed into either the control and intervention 
groups in the urban and rural areas. This educational module will be implemented over the course of 12 weeks as follows:

a. Before intervention

This process is to evaluate the baseline data before the implementation of the educational module program. Respondents from the control and intervention group will be asked to complete the pretest questionnaire, and their anthropometry will be measured such as weight, height, BMI, and body fat.

b. Implementation of the intervention educational module

The prevention educational module will be delivered over 12 weeks. A day of the implementation educational module the group for intervention will receive the health education and activities that have been planned in the module. The contents of the educational module consist of educational materials such as power points, videos, and games suitable for primary school children. The control group will receive the pamphlets and health education via PowerPoint and delivered through a lecture method related to healthy food, physical activity, and obesity prevention. Table 1 shows the themes in the module that will be emphasised for the primary school children based on a previous study. Meanwhile, parents for the control and intervention groups will also be educated on healthy nutrition, physical activity and a healthy lifestyle.

c. After the intervention educational module

The end of the intervention after 12 weeks, respondents from both the control and intervention groups will receive the same post-test questionnaire with the pre-test to evaluate the impact of the programme on the respondent. In addition, both respondents will measure their body composition such as anthropometry (weight, height, BMI, body fat).

\section{Methodology and timelines}

This study is quantitative with the use of an experimental method to examine the effect of the educational module on the respondents and time factor as suggested by Campbell \& Stanley (1966). In addition, this method also allows the pre-test with the intervention group followed by a post-test. Later on, this research design will be to evaluate the effects of the module with one time intervention before and after the evaluation test (Ghazali \& Sufean, 2017).Meanwhile, the study setting will be a primary school in Selangor because it has a higher number population of 188,501 primary school children as compared to other states (NHMS, 2015).

Another reason is the logistics factor. The population for this study is the school children from primary schools in the Jabatan Pendidikan Negeri Selangor. Purposive sampling will be used in this project to identify the school children aged 7 to 11 years old that will be involved and the sample will be selected from one class as suggested by Creswell (2008). Furthermore, the sample consists of primary school children and parents who agreed to participate in this study. The subjects are introduced as sample study unit. To ensure the sample size is adequate, sample size estimation was carried out using hypothesis testing for experimental studies by Lemeshow et al., (1990).

The minimum sample size calculated for this study is 60 participants (Thivel et al., 2011) or 30 participants per group after considering a $20 \%$ dropout rate. The inclusion criteria for the school children participate in this project are:

a. Aged 7 to 11 -year-old 
INTERNATIONAL JOURNAL OF ACADEMIC RESEARCH IN BUSINESS AND SOCIAL SCIENCES

Vol. 9, No. 2, Feb, 2019, E-ISSN: $2222-6990$ ๑ 2019 HRMARS

b. $\quad$ Agree to participant in this study.

c. Ability to complete the study intervention

The exclusion criteria for this project are:

a. School children that have been diagnosed with malnutrition and medical problem (selfdeclared or data from the school record)

b. The school children are absent during a day intervention

c. The school children who are following a special diet due to medical reasons

d. Inability to complete the study intervention

Phase 1

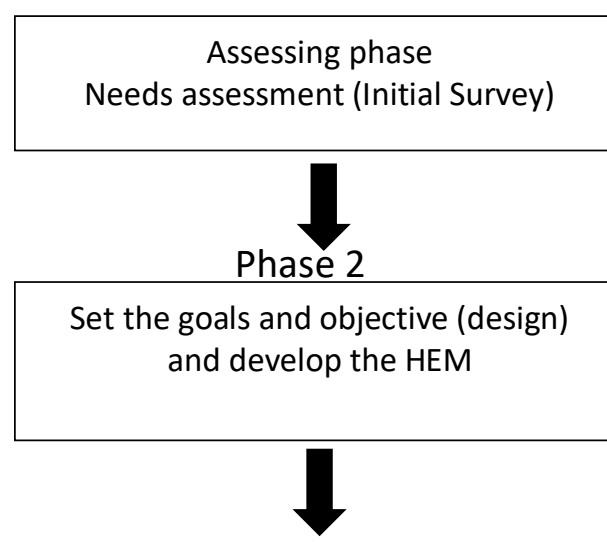

Phase 3

Implementing the intervention

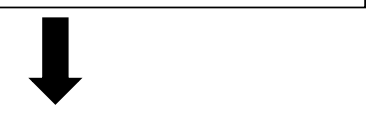

Evaluation

Knowledge

Practice behaviour

Attitude

Self-efficacy

BMI

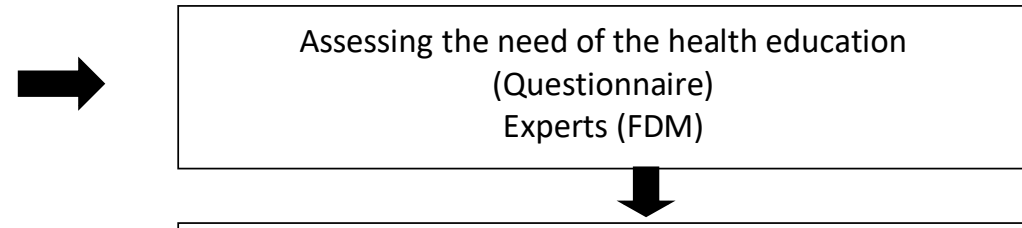

Set the goal and the objectives, health education method and set the health education activities (CHANGE Design)

Develop an educational module Experts Fuzzy Delphi Method (FGM)
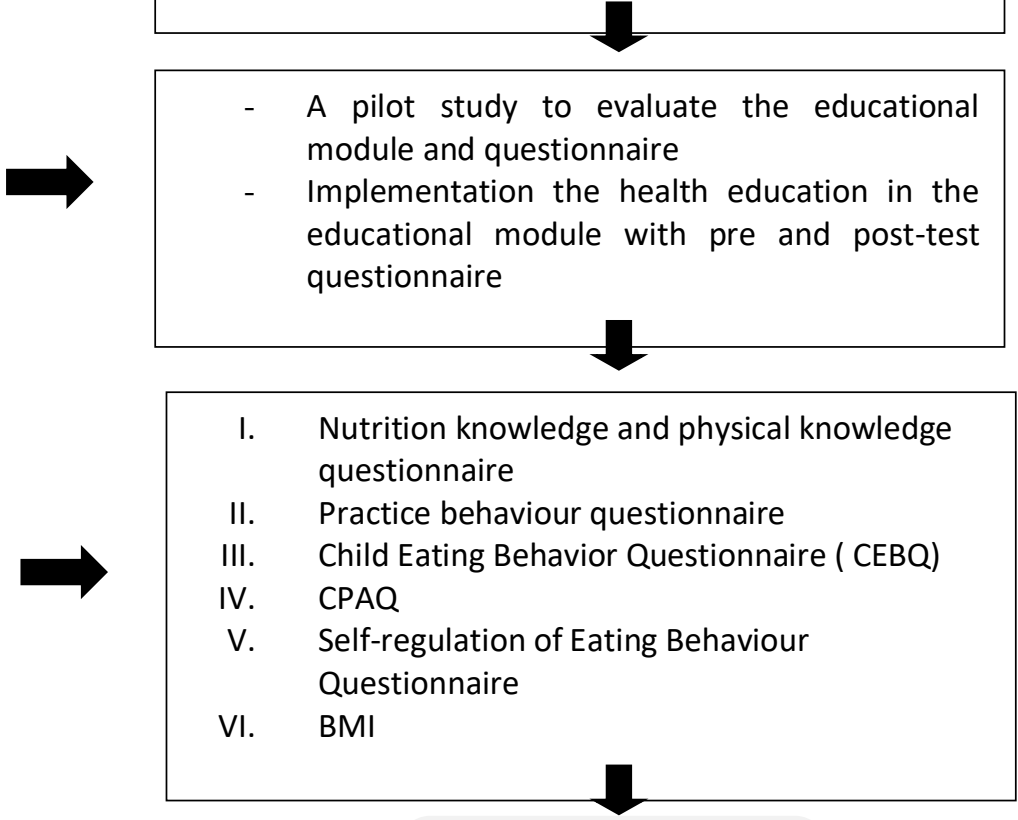

\section{Completed the Final}

HEM module

Figure 3: Study protocol for the project planning and development

The timeline of this project will take about two years to complete and, in the first year (2019), this project will be conducting needs assessment and the development of the module. After that, the 
INTERNATIONAL JOURNAL OF ACADEMIC RESEARCH IN BUSINESS AND SOCIAL SCIENCES

Vol. 9, No. 2, Feb, 2019, E-ISSN: 2222-6990 C 2019 HRMARS

module will be evaluated as part of a pilot study in the year 2020 before the module can be implemented in real time.

Table 1. Theme for the module programme

\begin{tabular}{|r|l|}
\hline \multicolumn{2}{|l|}{ CHOOSE HEALTHY NUTRITION } \\
\hline 1. & Eat a variety of healthy foods. \\
\hline 2. & Eat a healthy snack, fruit, and vegetables. \\
\hline 3. & Reduce the sweet beverages \\
\hline 4. & $\begin{array}{l}\text { Drink milk frequently and drinking much plain } \\
\text { water }\end{array}$ \\
\hline 5. & $\begin{array}{l}\text { Introduction to food pyramid as guidance for a } \\
\text { well-balanced diet }\end{array}$ \\
\hline 6. & $\begin{array}{l}\text { Helps family preparing and cooking healthy food } \\
\text { (demonstration) }\end{array}$ \\
\hline 7. & What is healthy eating habits including breakfast \\
\hline CHOOSE HEALTHY ACTIVITY \\
\hline 8. & $\begin{array}{l}\text { Healthy lifestyle and healthy behavior practice to } \\
\text { reduce the sedentary lifestyle }\end{array}$ \\
\hline 9. & Physical activity suitable for school children \\
\hline GUIDE EXERCISE \\
\hline 10 & Aerobic, jogging, walking, cycling, and swimming \\
\hline
\end{tabular}

\section{Validity and Pilot Study of The Hem and Study Instrument}

Validity is to examine whether the project instrument is able to measure the variables in this project. The questionnaire that will be used in this study will be evaluated by an expert in this area as well as piloted before actual implementation. The HEM module development will also be evaluated by experts using the Fuzzy Delphi Method (FDM). FDM is a new method introduced by Murray, Pappino, and Gisch (1995) that was modified from the Delphi technique. It uses a combination of Classic Delphi and numbering set fuzzy. FDM is one of the techniques used to get the comments from the expert through the fuzzy evaluation. It is widely used to get the comments continuously from the expert through the questionnaire. Meanwhile, using this method, it measures the level of consensus among the experts. FDM can get the comments from the expert without a round and more objective (Ho \& Wang, 2008). 
In this project, FDM will be used to get the comments from the expert to validate the HEM module and the questionnaire that will be used in this study. For this reason, it is important to determine the number of the expert panel that will be involved in this study and the criteria (Linstone, 1978). Moreover, Mullen (2003) suggested the minimum number of panel experts to be seven experts. In the process of the implementation of the FDM, the questionnaire of the panel experts is relevant and valid to determine the data. A Likert scale is commonly used. In this process, the first is to select the panel experts with several criteria such as expertise, certification, individual characteristic, discriminant ability, consistent and reliability, experience and knowledge, capacity and willingness to participate, sufficient time to participate in the Delphi and active in communication (Ramlan \& Ghazali,2018).

Furthermore, a pilot study will be conducted to examine the reliability of the questionnaire to the respondent from the study population or homogenous population. The purpose of the pilot study is to determine the internal consistency and test-retest reliability. A pilot study will be conducted using $10 \%$ of the actual sample size (Connelly, 2008) or 10 to 30 respondents as suggested by Hill (1998). The data from the pilot study will be analysed using SPSS Ver 23. This pilot study will help the researcher to determine whether the respondents understand the study instrument. Also, the researcher will assess and observe the respondents' willingness to answer the questionnaire, clarity, ambiguity of any words and instructions, the adequacy of time and to confirm the variables defined in the operational definitions. The respondents involved in the pilot study will be excluded from the intervention program.

The test-retest reliability and internal consistency is a standard method used in analysing the results of the pilot study (Netemeyer, 2013). Cronbach's alpha will be used to test the internal consistency of coefficients to establish reliability (Cronbach, 1990). A minimum reliability index is about 0.50 to be considered as acceptable (Jackson, 2006). Any item below 0.50 will be removed, and Cronbach test will be repeated. The last step is to improve the study instrument based on the validity and reliability.

\section{Benefits/ Anticipated outcome}

Obesity in Malaysia is increasing every year especially among school children where $25 \%$ of school children in the year 2015 were found to be obese as compared to $11.2 \%$ in the year 2011. Thus, the percentage consists of school children aged 10 to 17 years old (NHMS, 2015). The increase of $13.8 \%$ within five years is an alarming number for Malaysia. A previous study by Hoque, Kamaluddin, Abdul Razak, and Abdul Wahid (2016) in Selangor concluded that primary school children consume fried foods and skip breakfast regularly which are significantly linked to an unhealthy dietary pattern. It shows that the causes of obesity among primary school children are related to their eating habits besides physical inactivity.

The findings of this study will contribute to empirical evidence on how to correct eating habits and lead a healthy lifestyle among primary school children with the development education module and create an awareness campaign among primary school children in urban, suburban and rural areas. This education module is needed to reduce the obesity problem by significantly increasing the knowledge of nutrition, physical and obesity prevention. Besides that, it can improve self-efficacy among primary school children to practice a healthy lifestyle to prevent the development of obesity. 
INTERNATIONAL JOURNAL OF ACADEMIC RESEARCH IN BUSINESS AND SOCIAL SCIENCES

Vol. 9, No. 2, Feb, 2019, E-ISSN: 2222-6990 C 2019 HRMARS

\section{Acknowledgement}

Thank you to the Malaysian Ministry of Health, Malaysian Education, Universiti Teknologi Mara and Universiti Penguruan Sultan Idris and the individual that contribute to this project.

\section{Corresponding Author}

Norimah Said, Centre for Nursing Studies, Faculty Health Sciences, University Teknologi Mara (UiTM), UiTM Puncak Alam Campus, 42300 Puncak Alam, Selangor, MALAYSIA

Email: norimah2809@puncakalam.uitm.edu.my

\section{References}

Ahmad, M., \& Rahman, A. (2014). Chiildren's reaction towards the use of "child-frendly' learning environments in an obesity prevention health education program. Asian Social Science, 11, No 5;2015. doi:http;//dx.doi.org/10.5539/ass.v1In5p235

Ahmad Husairi K. 2014. Program Bersepadu Sekolah Sihat. Available at https://prezi.com/ qvs0ue4jes3y/program-bersepadu-sekolah-sihat-pbss/ (accessed 10 July 2018)

Akhtar-Danesh N, Dehghan M, Morrison KM, et al. (2011). Parents' perceptions and atti- tudes on childhood obesity: a Q-methodology study. J Am Acad Nurse Pract, 23(2), 67-75

American School Health Association. (2007). What is school health? Retrieved from http://www.ashaweb.org/whatis.html

Berry, D., Savoye, M., Melkus, G., \& Grey, M. (2007). An intervention for multiethnic obese parents and overweight children. Applied Nursing Research: ANR, 20(2), 63-71. https://doi.org/10.1016/j.apnr.2006.01.007

Campbell, D., \& Stanley, J. (1966). Experimental and Quasi-Experimental Design for Research. Boston: Houghton-Mifflin.

Centers for Disease Control and Prevention, (2018, October 26). Nutrition, Physical Activity and Obesity. Retrieved from https://www.cdc.gov/nutrition/index.html

Centers for Disease Control and Prevention Nutrition Examination Survey (NHANES). (2012). National Center for Health Statistics: Overweight among U.S. children and adolescents, National Health and Nutrition Examination Survey. http://www.CDC. gov/NCHS/NHANES.htm.

Connelly, L. M. (2008). Pilot studies. Medsurg Nursing, 17, 411-412

Cottrell, R.R., Girvan, J.T \& McKenzie, J.T. (2009). Principle and Foundations of Health Promotion and Education (4 Ed.). Pearson Benjamin Cummings, pp. 118-119.

Creswell, J.W. (2008). Educational research: Planning, conducting, and evaluating quantitative and qualitative research ( $3^{\text {rd }}$ ed.). Thousand Oaks, CA: Sage

Cronbach. (1990). Essentials of educational measurement.

Dewantari, N. M., \& Widiani, A. (2011). Fruits And Vegetables Consumption Pattern In School Children. Jurnal Skala Husada, 8, 119-125.

Foundations of Community and Public Health. (2018). Community Organizing / Building and Health Promotion Programming Assessing the Community. In Foundations of Community and Public Health (pp. 114-138). Jones \& Bartlett Learning LLC. Retrieved from samples.jbpub.com/9781284108415/9781284108491_CH05_Print.pdf 
INTERNATIONAL JOURNAL OF ACADEMIC RESEARCH IN BUSINESS AND SOCIAL SCIENCES

Vol. 9, No. 2, Feb, 2019, E-ISSN: $2222-6990$ ๑ 2019 HRMARS

Ghazali,D., \& Sufean,H. (2017). Methodologi Penyelidikan Dalam Pendidikan. Penerbit Universiti Malaya.( 3.ed). pp. 224-227.

He M. (2007). Are parents aware that their children are overweight or obese? do they care? Canadian Family Physician, 53(9), 1493-1499.

Hill, R. (1998). "What Sample Size is 'Enough' in Internet Survey Research"? Interpersonal Computing and Technology: An electronic Journal for the 21st Century. Available at: http://www.emoderators.com/ipct-j/1998/n3-4/hill.hmtl

Ho,Y.F., \& Chen,H.L. (2008). Applying the fuzzy Delphi method to select the variables of a sustainable urban system dynamics model. Conference of the System Dynamics, 1-21.

Hoque, K. E., Kamaluddin, M. A., Abdul Razak, A. Z., \& Abdul Wahid, A. A. (2016). Building healthy eating habits in childhood: a study of the attitudes, knowledge and dietary habits of schoolchildren in Malaysia. PeerJ, 4, e2651. https://doi.org/10.7717/peerj.2651

Institute for Public Health (IPH). (2013). NHMS2012-MalaysiaSchoolBasedNutritionSurvey.pdf.

J.Wardle, K.Parmenter, J. W. (2000). Nutrition knowledge and food intake. Appetite, 34(34), 269275. https://doi.org/doi:10.100doi:10.1006/appe.2000.03146/appe.2000.0314

Jackson-Leach, R., \& Lobstein, T. (2006). Estimated burden of paediatric obesity and co-morbidities in Europe. Part 1. The increase in the prevalence of child obesity in Europe is itself increasing. International Journal of Pediatric Obesity: IJPO: An Official Journal of the International Association for the Study of Obesity, 1, 26-32. https://doi.org/10.1080/17477160600586689

Kementerian Pendidikan Malaysia. (2015). Panduan Pengurusan Program Susu 1Malaysia ( Ps1M ). Retrieved from https://www.moe.gov.my/index.php/my/kesihatan/program-susu-1malaysia

Khodaveisi, M., Omidi, A., Farokhi, S., \& Soltanian, A. R. (2017). The Effect of Pender's Health Promotion Model in Improving the Nutritional Behavior of Overweight and Obese Women. International Journal of Community Based Nursing and Midwifery, 5(2), 165-174. Retrieved from http://www.ncbi.nlm.nih.gov/pubmed/28409170\%0Ahttp://www.pubmedcentral.nih.gov/arti clerender.fcgi?artid=PMC5385239

Kitzinger, H. B., \& Karle, B. (2013). The epidemiology of obesity. European Surgery - Acta Chirurgica Austriaca, 45(2), 80-82. https://doi.org/10.1007/s10353-013-0196-x

Kigaru DMD, Loechl C, Moleah T, Macharia- Mutie CW \& Ndungu ZW (2015). Nutrition knowledge, attitude and practices among urban primary school children in Nairobi City, Kenya: a KAP study. BMC Nutrition 1(44): 1-8.

Koyuncuoğlu Güngör, N. (2014). Overweight and Obesity in Children and Adolescents. Journal of Clinical Research in Pediatric Endocrinology. https://doi.org/10.4274/jcrpe.1471

Linstone,H.A. (1978). "The Dephi technque", in Fowles, R.B.(ed.), Handbook of Futures Research, Greenwood, Westport, CT,pp.271-300.

Ministy of Health Malaysia. (2012). Garis Panduan SALT. Garis Panduan Penjualan Makanan dan Minuman di Luar Pagar Sekolah. Retrieved from http://www.moh.gov.my

Ministry of Health Malaysia. (2015). Malaysian Dietary Guidelines. Retrieved from http://www.nutriweb.org.my/downloads.pdf

Ministry of Health Malaysia. (2008). Malaysia' Health. Retrieved from www.moh.gov.my.pdf

McKenzie, J.F.,Pinger,R.R., \& Kotecki, J.E. (2008). An Introduction to community health $\left(6^{\text {th }}\right.$ ed.).Boston:Jones and Bartlett. 
INTERNATIONAL JOURNAL OF ACADEMIC RESEARCH IN BUSINESS AND SOCIAL SCIENCES

Vol. 9, No. 2, Feb, 2019, E-ISSN: $2222-6990$ ๑ 2019 HRMARS

McKenzie, J. F., Neigher, B.L., \& Thackeray, R. (2009). Planning, Implementing, and evaluating health promotion programs:A primer ( $5^{\text {th }}$ ed.).San Francisco: Benjamin Cummings.

Murray, J.W. \& Hammons, J.O.(1995). Delphi: a versatile methodology forconducting qualitative research. Review of Higher Education, 18:4,23-36.

Mullen, P.M. (2003). Delphi,myth and reality, Journal of Health Organization and Management, Vol. 17 No 1,2003,pp.37-52.

Cameron, N.G., Norgan, G.H.E. (2006). childhood obesity. Broken Sound Parkway NW: Taylor \& Francis Group.

National Health and Morbidity Survey 2015 (NHMS, 2015). (2015). National Health and Morbidity Survey 2015 (NHMS 2015). Vol. II: Non-Communicable Diseases, Risk Factors \& Other Health Problems. Ministry of health (Vol. II). https://doi.org/10.1017/CB09781107415324.004

National Institute for Health and Care Excellence: Clinical Guidelines [Internet]. London: National Institute for Health and Care Excellence (UK); 2003-. Available from: https://www.ncbi.nlm.nih.gov/books/NBK11822/

Netemeyer, R.G. (2013). Scalling procedures: Issues and applications. doi:https://doi.org/10.4135/9781412985772

Pekmezi, D., Jennings, E., \& Marcus, B. H. (2009). Evaluating and enhancing self-efficacy for physical activity. Health \& Fitness Journal, 13(2), 16-21.

Ramlan, M., \& Ghazali, D. (2018). Aplikasi Kaedah Fuzzy Delphi Dalam Penyelidikan Sains Social.Penerbit Universiti Malaya,pp. 22-23

Sabramani, V. A. L., Idris, I. B., Sutan, R., Isa, Z. M., Buang, S. N., \& Ghazi, H. F. (2015). Managing obesity in malaysian schools: Are we doing the right strategies? Malaysian Journal of Public Health Medicine, 15(2), 75-83.

Savage, J., Fisher, J. \& Birch, L. (2007). Parental influence on eating behaviour: conception to adolescent, J Law, Medical \& Ethics Spring; 22-34

Schey, K. L., Luther, J. M., \& Rose, K. L. (2016). Are School Nurses an Overlooked Resource in Reducing Childhood Obesity? A Systematic Review and Meta-Analysis., 86(5), 1-21. https://doi.org/10.1021/acschemneuro.5b00094.Serotonin

Schultz, R. (2012). Prevalences of overweight and obesity among children in remote Aboriginal communities in central Australia. Rural and Remote Health, 12, 1872.

Sengmeuang, P., Kukongviriyapan, U., Pasurivong, O., Jones, C., \& Khrisanapant, W. (2010). Prevalence of obesity among Thai schoolchildren: A survey in Khon Kaen, Northeast Thailand. Asian Biomedicine, 4(6), 965-970.

Serene, T. E. H., Shamarina, S., \& Mohd, N. M. T. (2011). Familial and socio-environmental predictors of overweight and obesity among primary school children in Selangor and Kuala Lumpur. Malaysian Journal of Nutrition, 17(2), 151-162.

Slavin, J., \& Lloyd, B. (2012). Health Benefits of Fruits and Vegetables. Advances in Nutrition, 3(4), 506-516. https://doi.org/10.3945/an.112.002154.506

Sumarni Mohd, G., Muhammad Amir, K., Ibrahim Md, S., Mohd Rodi, I., Izzuna Mudla, M. G., \& Nurziyana, I. (2006). Obesity among schoolchildren in Kuala Selangor: a cross-sectional study. Tropical Biomedicine, 23(2), 148-154.

Surat Pekeliling Ikhtisas, B. 6/1998. (1998). Surat Pekeliling Ikhtisas, Bil 6/1998. Kementerian 
INTERNATIONAL JOURNAL OF ACADEMIC RESEARCH IN BUSINESS AND SOCIAL SCIENCES

Kesihatan Malaysia. Retrieved from https://www.moe.gov.my/images/pekeliling/2008/circularfile_file_000166.pdf

Siti Sabariah Buhari, R. A. (2017). Proses evaluation of the H.E.B.A.T! Program: A randomized control trial intervention to combat obesity in Negeri Sembilan. International Journal of Medical and Health Sciences, 11, No:11.

The Nutrition Society of Malaysia. (2014). Nutriweb. Retrieved from http://www.nutriweb.org.my

Triches, R.M. \& Giugliani, E.R.J. (2005). Obesity eating habits and nutritional knowledge among school children, Rev Saude Publica 39(4):1-7

Vio, F., Fretes, G., Montenegro, E., González, C. G., \& Salinas, J. (2015). Prevention of Children Obesity: A Nutrition Education Intervention Model on Dietary Habits in Basic Schools in Chile. Food and Nutrition Sciences, 06(13), 1221-1228. https://doi.org/10.4236/fns.2015.613128

World Health Organization, (2012). Obesity and Overweight, Fact Sheet No. 311, May.

World Health Organization. (Aug, 2014). Global Strategy on Diet, physical activity and health Childhood overweight and obesity. Retrieved from www.who.int/dietphysical activity/childhood/en/ 